\title{
THE PROPERTIES OF CHARCOAL FROM THE BLACK LIQUOR OF THE SODA PULPING OF RICE STRAW
}

\author{
Nyoman Jaya Wistara $^{1 *}$, Gokma Silaban ${ }^{1)}$, and Gustan Pari ${ }^{2)}$ \\ ${ }^{1)}$ Department of Forest Products, Faculty of Forestry, Bogor Agricultural University (IPB), \\ Kampus Dramaga IPB, Dramaga, Bogor - Indonesia 16680, Fax/phone: +622518621285 \\ ${ }^{2)}$ Forest Products Research Center, the Ministry of Forestry of the Republic of Indonesia, \\ Jl. GunungBatu, Ciomas, Bogor-Indonesia \\ ${ }^{*}$ Corresponding author: nwistara@ipb.ac.id
}

\begin{abstract}
The main goal of the present works was to determine chemical changes, thermal decomposition, and the content of moisture, ash, volatile, fixed carbon and calorific value of soda pulping black liquor of the rice straw. Neutralized black liquor was dried to a moisture content of $10 \%$ and then pyrolized at $106^{\circ} \mathrm{C}-750^{\circ} \mathrm{C}$. It was found that calorific value, fixed carbon, volatile mater, and moisture content were in the range of 2782-4716 cal/g, 49.2-81.6\%, 15.5-47.5\%, and 0.2-3.5\%, respectively. Ash content was not influenced by the temperature of pyrolysis and was thought to depend on its initial silicate content. The weight loss of pulp was higher than that of black liquor. Extreme weight loss has been found in the temperature of $200-400^{\circ} \mathrm{C}$. Noticeable functional groups changes were found with the increasing temperature of pyrolysis. Hydroxyl group completely disappeared at $300^{\circ} \mathrm{C}$ and above. Carbonyl related groups were also disappeared at $300-500^{\circ} \mathrm{C}$, but it was reformed at 650 and $750^{\circ} \mathrm{C}$. It might be brought about by the deformation of chemical bonding of oxygen ring in lignin structures.
\end{abstract}

Keywords: black liquor; functional groups; pyrolysis; weight loss

\begin{abstract}
Abstrak
SIFAT-SIFAT ARANG LINDI HITAM DARI PEMASAKAN JERAMI DENGAN LARUTAN SODA API. Penelitian ini bertujuan untuk menentukan perubahan sifat kimia, dekomposisi termal dan kadar air, abu, zat terbang, karbon terikat serta nilai kalor arang lindi hitam pemasakan soda jerami padi. Dalam penelitian ini, lindi hitam netral dikeringkan (kadar air 10\%), kemudian dipirolisis pada selang suhu $100-750^{\circ} \mathrm{C}$ di dalam reaktor berpengatur suhu. Hasil penelitian menunjukkan bahwa nilai kalor, karbon terikat, zat terbang dan kadar air masing-masing berselangdari 2782-4716 cal/g, 49,2-81,6\%, 15,5-47,5\%, dan 0,2-3,5\%. Kadar abu tidak dipengaruhi oleh suhu pirolisis dan diduga bergantung pada kadar silika bahan bakunya. Nilai kalor meningkat dengan meningkatnya kadar karbon terikat. Perilaku kehilangan berat arang dari lindi hitam berbeda dengan perilaku kehilangan berat pulp jerami. Kehilangan berat pulp lebih tinggi dari kehilangan berat arang lindi hitam. Kehilangan berat yang tajam terjadi pada selang suhu $200-400^{\circ} \mathrm{C}$. Perubahan gugus fungsi yang nyata terjadi dengan meningkatnya suhu pirolisis. Gugus hidroksil menghilang pada suhu $300^{\circ} \mathrm{C}$ atau lebih. Gugus terkarbonilasi menghilang pada suhu $300-500^{\circ} \mathrm{C}$, tetapi terbentuk kembali pada suhu $650^{\circ} \mathrm{C}$ dan $750^{\circ} \mathrm{C}$. Hal ini kemungkinan disebabkan oleh deformasi ikatan kimia oksigen di dalam cincin dari struktur lignin.
\end{abstract}

Kata kunci: lindi hitam; gugus fungsi; pirolisis; kehilangan berat

\section{INTRODUCTION}

Stock diminution of fossil fuel has urged the finding of renewable sources for alternatives. Even though renewable energy such as hydropower and solar energy have been used to a minor extent, Demirbas (2006) has signified that future renewable energy will be mainly based on lignocellulosic biomass. Lignocellulosic biomass can be derived from energy plantation as well as from the processing wastes of agricultural products, wood industry and organic component of municipal solid waste. In a more specific purpose, these non-food biomasses are possible and challenging to be developed as an alternative for the future transportation fuels (Mousavioum and Doherty, 2010).

Organic waste contained in black liquor of pulping process is very promising raw material for renewable energy. Black liquor consists of lignin 
(approximately 46\% of total solid content), degraded carbohydrates and extractives (Sjostrom, 1993). In chemical recovery processes of kraft pulping, the organic components of black liquor are converted into energy and the inorganic components are recycled for cooking chemical. However, in most soda pulping mills, chemical recovery processes are not well established as that in kraft process. Thus, lignin from black liquor of soda pulping process can be converted into valuable charcoal, a form of renewable energy commonly used in many industrial endeavors (Kituyi, 2004; Rousset et al., 2011).

Charcoal is porous solid carbon residue from oxygen deficient combustion of biomaterial. Most of pores are usually blocked by hydrocarbon, tar and other organic compounds. Charcoal consists of fixed carbon, ash, moisture, nitrogen and sulfur. A quality charcoal has been characterized as having fixed carbon of more than $75 \%$, ash content of less than $5 \%$, volatile content below $15 \%$, free of contaminants and relatively robust (Komarayati et al., 1997). Calorific value is also considered as an important factor determining the quality of charcoal (Hendra and Darmawan, 2000).

In pyrolysis, every chemical component of biomass will be decomposed at a specific temperature. Hemicelluloses, cellulose, and lignin decomposed at $180-350^{\circ} \mathrm{C}, 275-350^{\circ} \mathrm{C}$ and 250 $500^{\circ} \mathrm{C}$, respectively (Kim et al., 2006). Extractives and some hydroxyl acid will be decomposed at 100$200^{\circ} \mathrm{C}$ (Guo et al., 2008). Decomposition of lignin produces particular compounds that are dependent on pyrolyzed wood species. Wood charcoal, a product of pyrolysis process, retains a higher calorific value. Calorific value of wood has been reported to be in the range of $4350-4625 \mathrm{cal} / \mathrm{g}$ and the calorific value of wood charcoal was in the range of $6960-7180 \mathrm{cal} / \mathrm{g}$ (Komarayati et al., 1997).

As for wood, the calorific value of black liquor is thought can be improved through pyrolysis process.
However, appropriate utilization of black liquor as renewable energy requires sufficient information on its pyrolytic characters. It has been reported that the type of biomass influenced its pyrolytic character. For instance, carbonization of crack firewood of Quercussideroxyla was slower, nevertheless with higher yield compared to these of its branches (Bustamante-Garcia et al., 2013).Thermo gravimetric analysis also indicated that biomass with different content of lignin, hemicelluloses and cellulose decomposed at distinctly different temperature of pyrolysis (Burhennea et al., 2013). Considering that the properties of pyrolysis products of biomass are determined by its types, the present research was intended to determine the pyrolytic characters and properties of charcoal resulted from the pyrolysis of soda pulping black liquor. It is expected that by understanding its pyrolytic characters, lignin from soda pulping black liquor can be properly used as a source of renewable energy.

\section{MATERIALS AND METHODS}

Black liquor of rice straw soda pulping was obtained from PT. Kertas Padalarang, a state pulp and paper mill at Padalarang, West Java. The solid content of the black liquor was approximately $10 \%$ (w/w). As indicated by the outline of experimentation in Figure 1, the black liquor was neutralized with $7 \%$ sulfuric acid solution and evaporated to isolate the solid component. Isolated solid was then dried to approximately $10 \%$ moisture content. Pyrolysis of dried solid was carried out in a stainless steel thermocoupled reactor. Pyrolysis temperature was varied at $100,200,300,400,500,650$, and $750^{\circ} \mathrm{C}$. For every level of temperature, $150 \mathrm{~g}$ of sample was pyrolyzed within the period of 1 hour. Two replications were made in each temperature of pyrolysis. The resulting data were then averaged and was descriptively explained.

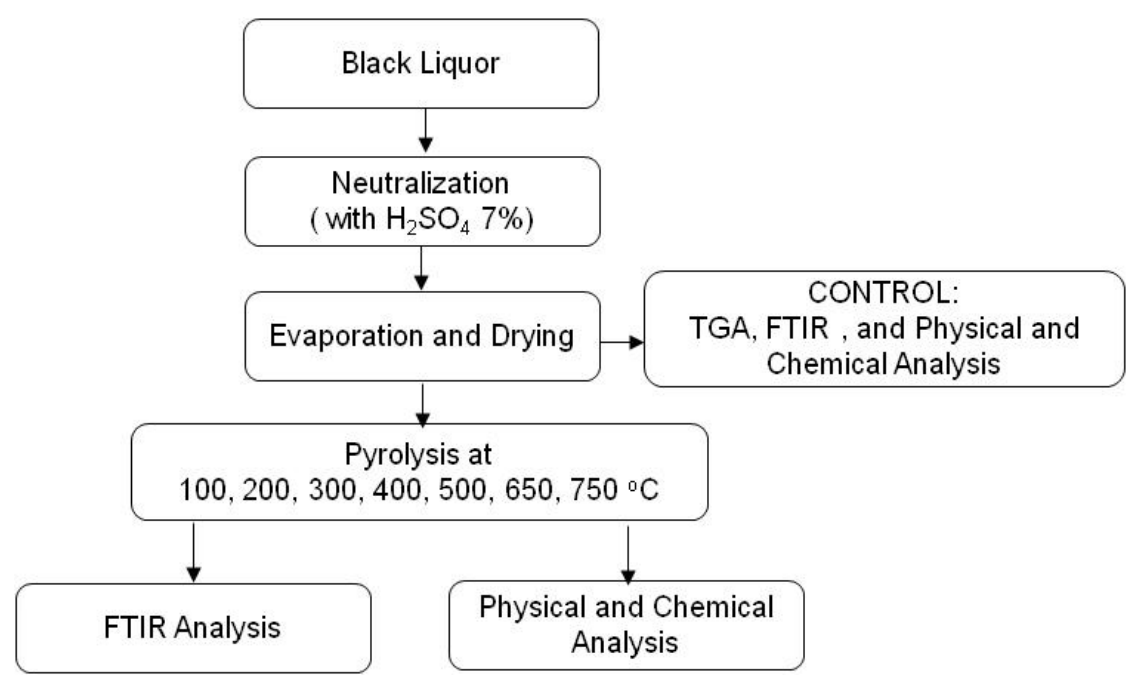

Figure 1. Outline of the present experiments 
Chemical change of the products due to the temperature of pyrolysis was examined by $\mathrm{KBr}$ method using FTIR Hitachi 270-50 Spectrophotometer. In this method, $2 \mathrm{mg}$ of sample was thoroughly mixed with $100 \mathrm{mg} \mathrm{KBr}$ and ground to a fine powder. The mixture was then formed into pellet, vacuumed and scanned with FTIR at 4000$4000 \mathrm{~cm}^{-1}$ wave number. The resulting absorbance was analyzed to determine chemical change of sample during pyrolysis process.

Thermal decomposition of the charcoal and soda pulp of rice straw (as comparison) was determined by the use Shimadzu DTG-60H Simultaneous DTA-TGA Apparatus. In this procedure, sample was ground and screened to pass approximately 50 mesh sieve. Then, a $2.3 \mathrm{mg}$ of fine sample was analyzed at app. $30-800^{\circ} \mathrm{C}$ with the heating rate of $20^{\circ} \mathrm{C} / \mathrm{min}$. An equal amount of $\alpha$ alumina $\left(\alpha-\mathrm{Al}_{2} \mathrm{O}_{3}\right)$ powder was simultaneously run for control. Proximate analysis of the resulted charcoal was determined in accordance with ASTM standards. Moisture content, ash content, volatile content and fixed carbon were determined in accordance with ASTM 1979 standard method. Calorific value was determined based on ASTM 1984 standard method.

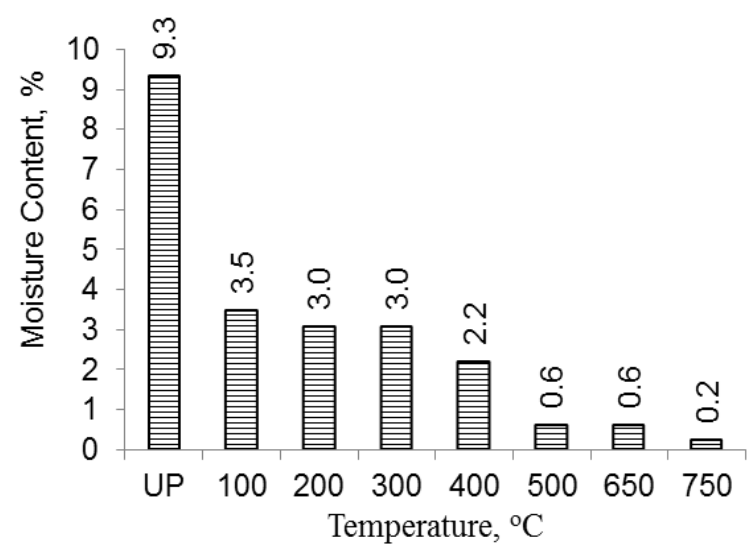

(a)

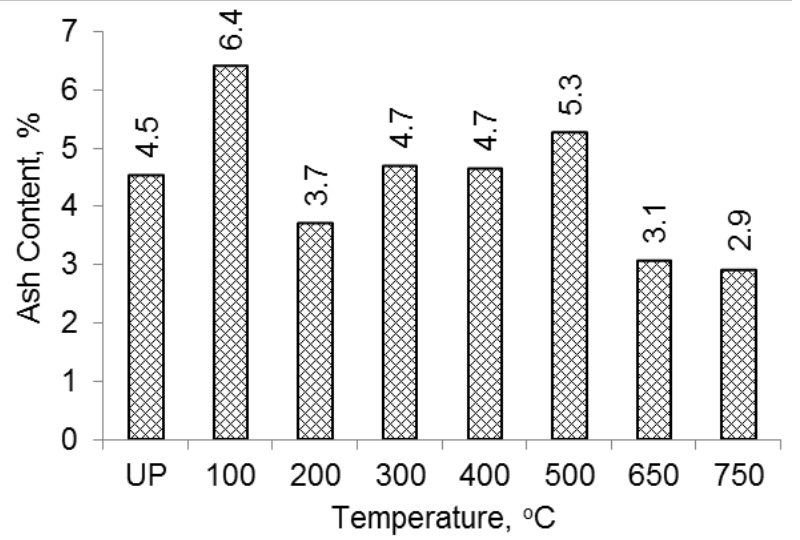

(c)

\section{RESULTS AND DISCUSSION}

Proximate Analysis

The temperature of pyrolysis was found influencing moisture content, volatile content and fixed carbon, but the ash content of the resulted charcoal were fluctuating. The increase of pyrolysis temperature decreased moisture and volatile content, but it increased the fixed carbon as indicated by Figure 2.

It can be seen from Figure 2 that moisture content sharply decreased up to pyrolysis temperature of $500^{\circ} \mathrm{C}$. Afterward, moisture content was relatively constant. This pattern can be originated by the fast evaporation of free water at $100-500^{\circ} \mathrm{C}$. Pyrolysis at an extreme temperature (above $500^{\circ} \mathrm{C}$ ) brought about the degradation of lignin and cellulose (Guo et al., 2008). At the temperature of $500-750^{\circ} \mathrm{C}$ carbon chains in cellulose, hemicelluloses and lignin polymers are broken (Nugraha and Fatimah, 2005) that possibly resulted in the release of bound water. Evaporation of bound water, in which its amount is very small compared to that of free water, did not sharply decrease the moisture content. Moisture content of the resulting charcoal at pyrolysis temperature of $100-750^{\circ} \mathrm{C}$ was lower than $6 \%$ and satisfied the maximum moisture content required by SNI 1989. The moisture content of high quality charcoal must be low (Hendra and Winarni, 2003).

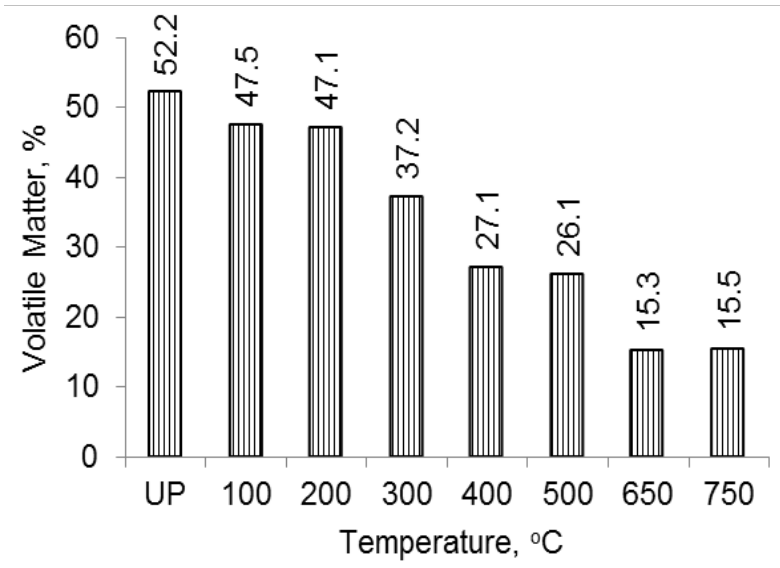

(b)

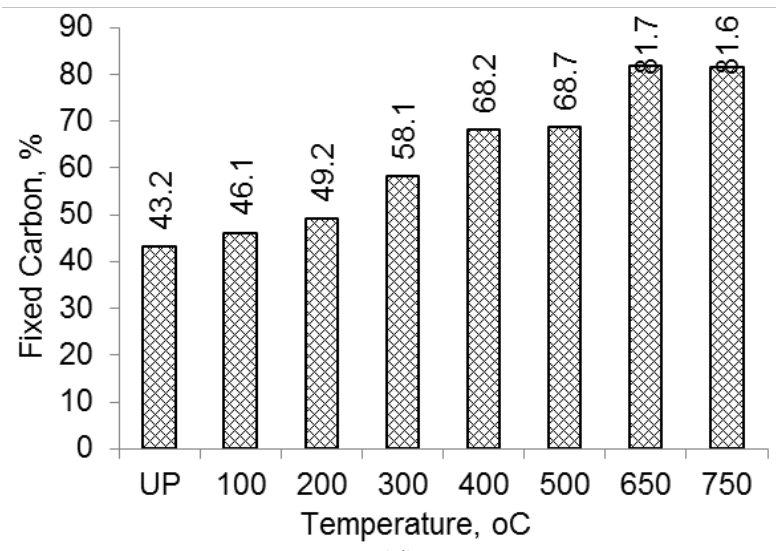

(d)

Figure 2.The content of moisture (a), volatile matter (b), ash (c), and fixed carbon (d) at various pyrolysis temperatures (Note: UP is non-pyrolyzed sample). 
Volatile is substances, other than water, resulted from decomposition of certain compounds contained in charcoal. Present experiments indicated that volatile content of charcoal decreased with the increased of pyrolysis temperature and it was in the range of $15.26-52.24 \%$. The decrease of volatile content with increasing of temperature can be brought about by the decrease of compounds that readily decomposed by thermal treatment and the completion of pyrolysis process. Completion of pyrolysis is indicated by the increased of fixed carbon with increasing of pyrolysis temperature. Volatile in charcoal is actually not preferred due to the release of smoke in its combustion (Hendra and Winarni, 2003). Even though Figure 2 indicates that the ash content tends to decrease with increasing pyrolysis temperature, statistical evaluation revealed that they did not significantly different. Ash content is determined by the inorganic component of black liquor (Hendra and Darmawan, 2000) and do not burn down at any pyrolysis temperature. The present finding is in agreement with the results of Zapusek et al. (2003).

Figure 2 indicates that the increase of pyrolysis temperature increased fixed carbon content. Fixed carbon content found in this experiment was ranged from $43.2 \%$ to $81.7 \%$. Pyrolysis at the temperature of $100-200^{\circ} \mathrm{C}$ brought about dehydration and thermal decomposition of extractives and hydroxyl acid groups (Guo et al., 2008) that excluded hydrogen and oxygen components, thus increased the purity of charcoal as indicated by the increased of fixed carbon content (Sjostrom, 1993). Fixed carbon content is an important parameter determines the quality of charcoal. Fixed carbon of high quality charcoal must be higher than 75\% (Komarayati et al., 1997). Present experiments indicated that pyrolysis at $650^{\circ} \mathrm{C}$ and $750^{\circ} \mathrm{C}$ produced charcoal with $82 \%$ fixed carbon. Therefore, high quality charcoal from black liquor of soda pulping can be produced through pyrolysis at temperature above $500^{\circ} \mathrm{C}$.

\section{Calorific Value}

Calorific value indicates the quantity of heat resulted from the combustion reaction of charcoal at a given volume. In the present research, calorific value of charcoal from black liquor of soda pulping was ranged from 2782-4716 (cal/g). Calorific value is affected by moisture content, fixed carbon, volatile and ash content. Lignin is the predominant chemical component determines the calorific value due to its high carbon content. Calorific value of wood black liquor with $42 \%$ of carbon content was found higher than that of bagasse black liquor that contain only 33.1\% carbon (Nassar, 2003). Figure 3 indicates the relationship between calorific value and moisture content, fixed carbon and volatile substances. Calorific value increased with the increasing of pyrolysis temperature. Pyrolysis of soda pulping black liquor at $650-750^{\circ} \mathrm{C}$ produced charcoal with comparable calorific values to those of several wood species, but lower than calorific value of wood charcoal reported by Komarayati et al., (1997). These authors reported that the calorific values of wood and wood charcoal was 4350-4625 (cal/g) and 6960-7180 $\mathrm{cal} / \mathrm{g}$, respectively. The charcoal was produced by pyrolysis process at $500^{\circ} \mathrm{C}$ for 12 hours resident time.

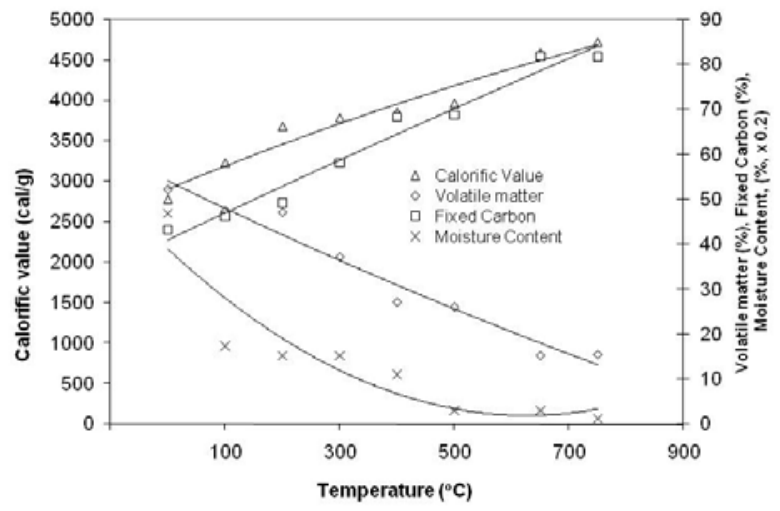

Figure 3. Trend in calorific value, moisture content, fixed carbon and volatile matter at different temperature of pyrolysis

Ash and volatile content negatively affect calorific value (Hendra and Darmawan, 2000). Ash and volatile content of the currently resulting charcoal pyrolyzed at $500^{\circ} \mathrm{C}$ was $5.3 \%$ and $26.1 \%$, respectively. These finding are higher than those reported by Komarayati et al. (1997) for charcoal from several wood species. These authors found that ash and volatile content of wood charcoal was 1.04$3.86 \%$ and $17.12-20.23 \%$, respectively. Therefore, the high ash and volatile content of the present charcoal is thought to bring about its low calorific value.

\section{The Yield ofPyrolysis}

The yield of pyrolysis decreased with increasing temperature. Table 1 indicates that the yield of pyrolysis in the present research was ranged from 42.7 to $88.7 \%$. Pyrolysis at $750^{\circ} \mathrm{C}$ resulted in a lowest yield and pyrolysis at $100^{\circ} \mathrm{C}$ was giving the highest yield. Products distribution of pyrolysis is influenced by pyrolysis temperature. The increase of pyrolysis temperature tended to increase gas and liquid, and decreased the solid (charcoal) quantity (Duman et al., 2011).

Table 1.The yield of pyrolysis at different temperature

\begin{tabular}{cc}
\hline Temperature $\left({ }^{\circ} \mathrm{C}\right)$ & Yield $(\%)$ \\
\hline 100 & 88.66 \\
200 & 71.33 \\
300 & 65.66 \\
400 & 51.33 \\
500 & 48.66 \\
650 & 45.66 \\
750 & 42.66 \\
\hline
\end{tabular}




\section{Thermogravimetric Analysis}

Weight loss during pyrolysis processes was determined through thermogravimetric analysis. Figure 4 indicates the curve of TGA and DTA of black liquor and soda pulp of rice straw (as comparison). It can be seen that five stages of weight loss of black liquor and pulp could be assigned during thermal decomposition carried out from $30^{\circ} \mathrm{C}$ to $900^{\circ} \mathrm{C}$. In average, the weight loss of black liquor is in the lower rate compared to that of pulp. Pulp suffered a very sharp weight loss at $232-436^{\circ} \mathrm{C}$ and at a much slower rate after $436^{\circ} \mathrm{C}$. The response of chemical components of wood toward thermal degradation is different, and this can be the origin of the difference of weight loss pattern between pulp and black liquor (Hussain et al., 2006; Guo et al., 2008). Hemicelluloses and cellulose is thermally decomposed at $200-350^{\circ} \mathrm{C}$, and lignin at $280-500^{\circ} \mathrm{C}$ (Nugraha and Fatimah, 2005). Weight loss of black liquor was in a more uniform rate, perhaps due to the lower content of its cellulose and hemicelluloses. Lignin content of black liquor in the present experiment was approximately 38\%.

The characteristics of weight loss in every stage are listed in Table 2. Total weight loss of pulp was higher than that of black liquor presumably due to cellulose content of pulp was higher than its lignin content. On the other hand, cellulose content of black liquor was certainly lower than its lignin content. Shafizadeh (1984) and Worasuwannarak et al. (2004) previously found that weight loss of lignin was lower than that of cellulose at high pyrolysis temperature.

The temperature at maximum rate of weight loss of the first stage was occurred at $100^{\circ} \mathrm{C}$ both for charcoal and pulp with weight loss of approximately $10 \%$. Weight loss in this stage was mostly associated with the moisture loss (Mousavioun and Doherty, 2010; Zhao and Liu, 2010). Predominant weight loss occurred at the second and third stages reaching approximately $24 \%$ and $45 \%$ with temperature at maximum rate of weight loss at $350^{\circ} \mathrm{C}$ and $357^{\circ} \mathrm{C}$, respectively for charcoal and pulp. These stages involved the decomposition of hemicellulose, cellulose and lignin. Hemicelluloses and cellulose have been reported to decompose at $200-350^{\circ} \mathrm{C}$ (Nugraha and Fatimah, 2005) and lignin at $200-500^{\circ} \mathrm{C}$ (Nugraha and Fatimah, 2005; Zhao and Liu, 2010). Lignin decomposition can be assumed to contribute the most in the third stage of weight loss. In the temperature range of $200-500^{\circ} \mathrm{C}$, pyrolytic degradation involves the decomposition of aromatic rings (Tejado et al., 2007), and lignin is composed mainly by aromatic ring structured chemicals. In the fourth and fifth stages, the weight loss of pulp was leveled off (approximately 10\%) and that of the charcoal was remain high (approximately 25\%). Further decomposition of aromatic rings possibly occurred at $500-900^{\circ} \mathrm{C}$ (Yuan et al., 2009). Charcoal indeed contains higher lignin than that of pulp.

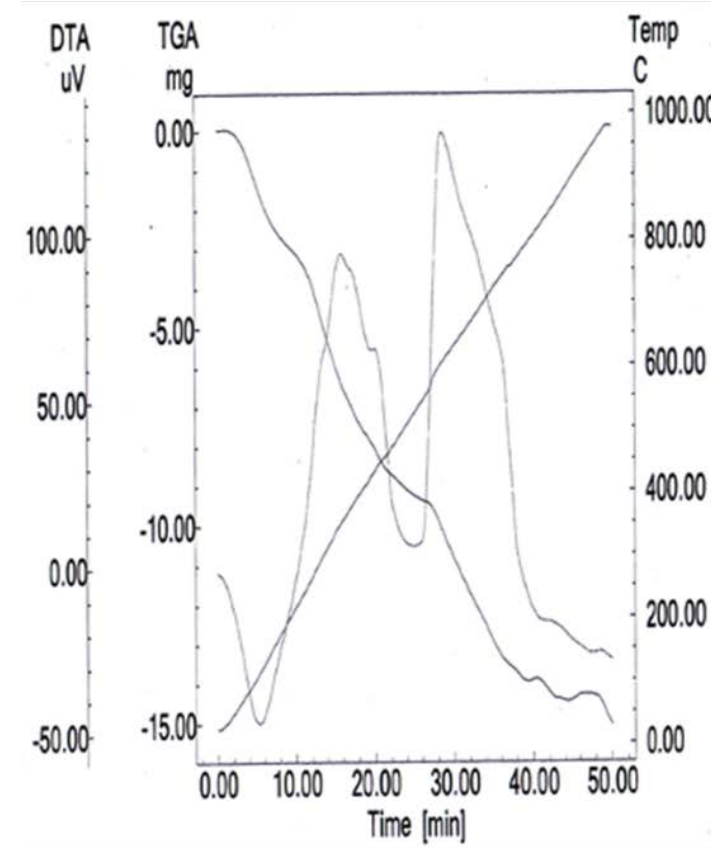

(a)

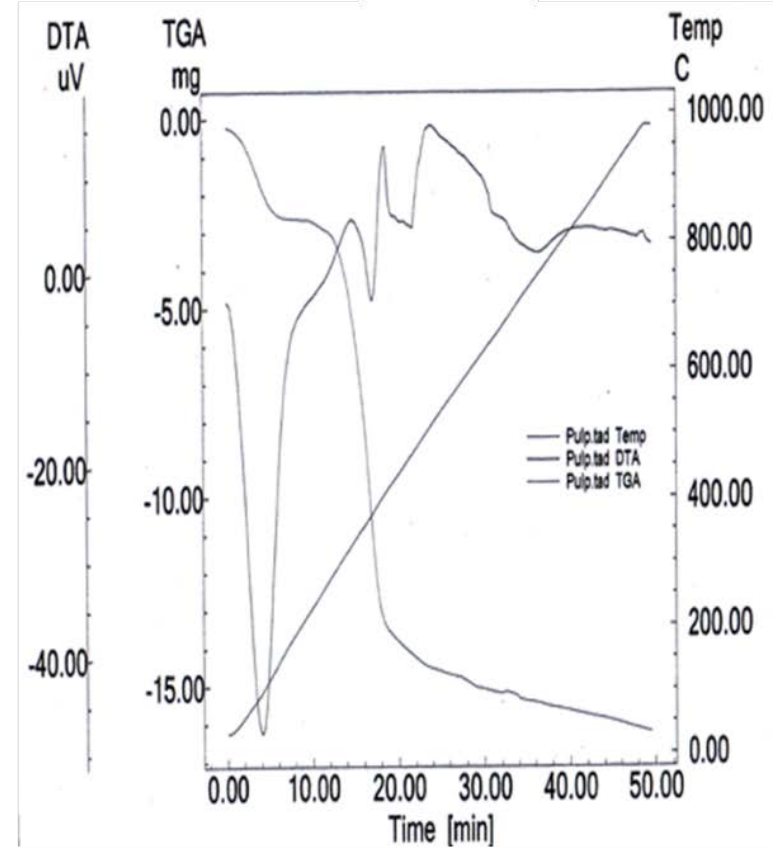

(b)

Figure 4.The TGA and DTA curve of charcoal from black liquor (a) and soda pulp of rice straw (b). 
Table 2.Weight loss characteristics of the resulting charcoal and pulp from soda pulping of rice straw

\begin{tabular}{ccccccccc}
\hline \multirow{2}{*}{ Stage } & \multicolumn{2}{c}{$\begin{array}{c}\text { Temperature Range } \\
\left({ }^{\circ} \mathrm{C}\right)\end{array}$} & \multicolumn{2}{c}{$\begin{array}{c}\text { Temperature at maximum } \\
\text { rate of weight loss }\left({ }^{\circ} \mathrm{C}\right)\end{array}$} & Weight loss (\%) & \multicolumn{3}{c}{$\begin{array}{c}\text { Cumulative weight loss } \\
(\%)\end{array}$} \\
\cline { 2 - 10 } & Charcoal & Pulp & Charcoal & Pulp & Charcoal & Pulp & Charcoal & Pulp \\
\hline I & $30-143$ & $30-138$ & 100.0 & 100.0 & 9.95 & 9.69 & 9.95 & 9.69 \\
II & $143-232$ & $138-275$ & 221.4 & 253.9 & 5.10 & 3.32 & 15.05 & 13.01 \\
III & $232-436$ & $275-400$ & 350.0 & 357.7 & 19.13 & 42.09 & 34.18 & 55.10 \\
IV & $436-586$ & $400-488$ & 525.0 & 425.0 & 4.60 & 4.08 & 38.78 & 59.18 \\
V & $586-900$ & $488-900$ & 675.0 & 742.3 & 19.89 & 5.62 & 58.67 & 64.80 \\
\hline
\end{tabular}

Table 3.The infra-red absorbance of black liquor pyrolyzed at different temperature

\begin{tabular}{cr}
\hline Temperature $\left({ }^{\circ} \mathrm{C}\right)$ & Wave Number $\left(\mathrm{cm}^{-1}\right)$ \\
\hline Lignin & $3463-2800-1750-1300-1200-900-800$ \\
100 & $3436-2900-1700-1350-1200-950-600$ \\
200 & $3440-2900-1700-1000-600$ \\
300 & $2900-1600-750-750$ \\
400 & $1600-1000-900-750-700$ \\
500 & $1500-1100-800-600$ \\
650 & $2800-1700-800-700$ \\
750 & $2900-1700-800-700$ \\
\hline
\end{tabular}

\section{Chemical Changes}

The change of functional groups in pyrolyzed black liquor was determined with FTIR method. The wave number absorbance of FTIR spectra of black liquor are listed in Table 3 and absorbance patterns are indicated in Figure 5.

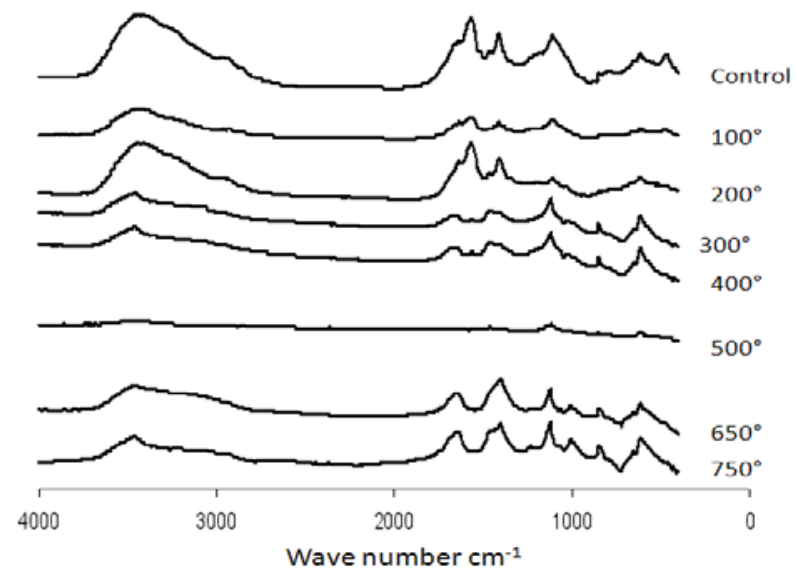

Figure 5. FTIR spectrogram of black liquor pyrolyzed at different temperature.

Table 3 indicates that during pyrolysis processes, the changes of chemical structure occurred as indicated by the change in the pattern of wave number spectra. Thermal treatment brought about cleavages of certain functional groups and the formation of new groups (Pari et al., 2003). The bands of IR absorbance of black liquor (Table 3) at the wave number range of $1750-2800 \mathrm{~cm}^{-1}$ indicates the presence of $\mathrm{OH}$ group bound through hydrogen bond. The existence of $\mathrm{C}-\mathrm{H}$ group aromatic indicated by absorbance at wave number of $700-800 \mathrm{~cm}^{-1}$ was also noticed. Even though the pattern of IR spectra at $100^{\circ} \mathrm{C}$ and $200^{\circ} \mathrm{C}$ were similar to that of control (lignin), bond cleavage and the formation of aromatic compound was thought to occur as indicated by decreasing $\mathrm{C}-\mathrm{H}$ intensity. At $300^{\circ} \mathrm{C}$, broadening of band at the wave number of $1600-2900 \mathrm{~cm}^{-1}$ indicating the presence of carboxylic acid group $(\mathrm{OH})$ and absorbance in this area strengthen the indication of aromatic (C=C) dominance (Pari et al., 2003).

IR spectra of black liquor pyrolyzed at $400^{\circ} \mathrm{C}$ and $750^{\circ} \mathrm{C}$ indicated a similar pattern, i.e. a low intensity in the wave number of $1700-2900 \mathrm{~cm}^{-1}$ and band broadening and decreasing intensity occurred in the wave number of $600-800 \mathrm{~cm}^{-1}$. Vibration of functional group at the wave number of 1700-2700 $\mathrm{cm}^{-1}$ indicates the presence of $\mathrm{O}-\mathrm{H}$ of carboxylic acid. The occurrence of functional group $\mathrm{C}-\mathrm{H}$ aromatic is indicated by absorbance at the wave number of 700 $800 \mathrm{~cm}^{-1}$. The pattern of IR spectra indicates that the intensity of absorbance at $600-800 \mathrm{~cm}^{-1}$ decreased with increasing pyrolysis temperature. Carboxylic acid tends to form hydrogen bonding that will diminish with heating at high temperature in pyrolysis process. Pyrolysis brought about the change in functional group of isolated solid of black liquor indicated by the change in the pattern of IR spectra by the increase of pyrolysis temperature. Similar finding was reported by Pari et al. (2004).

\section{CONCLUSIONS}

Increasing pyrolysis temperature increased the fixed carbon and calorific value, and decreased moisture content and volatile substances. Ash content of charcoal was determined by the ash content of raw material, thus it did not influence by pyrolysis temperature. The weight loss of charcoal from black liquor of the rice straw soda pulping and its pulp occurred at five different stages. The weight loss rate of black liquor was lower than that of pulp most likely due to the higher content of cellulose in pulp. Degradation of cellulose at $232-436^{\circ} \mathrm{C}$ brought about a very sharp increase of weight loss in pulp and at a much slower rate after $436^{\circ} \mathrm{C}$. Pyrolysis brought about 
chemical change in charcoal. Hydroxyl group completely disappeared at $300^{\circ} \mathrm{C}$ and above. Carbonyl group disappeared at $300-500^{\circ} \mathrm{C}$; however it reformed at $650^{\circ} \mathrm{C}$ and $750^{\circ} \mathrm{C}$ presumably due to deformation of oxygen chemical bonding in the ring structure.

\section{REFERENCES}

Burhennea, L., Messmera, J., Aichera, T., and Laborieb, M.P., (2013), The effect of the biomass components lignin, cellulose and hemicellulose on TGA and fixed bed pyrolysis, J. Anal. Appl. Pyrol., 10, pp. 177-184.

Bustamante-Garcia, V., Carrillo-Parra, A., GonzálezRodríguez, H.Ramírez-Lozano, R.G., Corral-Rivas, J.J., and Garza-Ocanas, F., (2013), Evaluation of a charcoal production process from forest residues of QuercussideroxylaHumb., \& Bonpl. in a Brazilian beehive kiln, Ind. Crops Prod., 42, pp. 169-174.

Demirbas, M.F., (2006), Current Technologies for Biomass Conversion into Chemicals and Fuels, Energy Sources, Part A, 28, pp. 1181-1188.

Duman, G., Okutucu, C., Ucar, S., Stahl, G., and Yanik, J., (2011), The slow and fast pyrolysis of cherry seed, Bioresour. Technol., 102, pp. 1869-1878.

Guo, Y.L., Wu, S.B., Guo, Q.X., and Wang, G.S., (2008), Thermogravimetric Analysis of Pyrolysis Characteristics of Kraft Black Liquor. www.frc.kie/kr/down/p1-32. [14 November 2008].

Hendra, D. and Darmawan, S., (2000), Pembuatan Briket Arang dari Serbuk Gergajian Kayu dengan Penambahan Tempurung Kelapa, Buletin Penelitian Hasil Hutan, 18(1), hal.1-9.

Hendra, D. dan Winarni, I., (2003), Sifat Fisis dan Kimia Briket Arang Campuran Limbah Kayu Gergajian dan Sebetan Kayu, Buletin Penelitian Hasil Hutan, 21(3), hal. 211-226.

Hussain, A., Ani, F.N., Darus, A.N., and Ahmed, Z., (2006), Thermogravimetric and Thermochemical Oil Palm Shell Waste, Jurnal Teknologi, 45 (A), pp. 4353.

Kim, H.S., Kim, S., Kim, H.J., and Yang, H.S., (2006), Thermal properties of bio-flour-filled polyolefin composites with different compatibilizing agent type and content, Thermochim. Acta, 451, pp. 181-188.

Kituyi, E., (2004), Towards sustainable production and use of charcoal in Kenya: exploring the potential in life cycle management approach, J. Clean. Prod., 12, pp. 1047-1057.
Komarayati, S., Nurhayati, T., dan Setiawan, D., (1997), Hasil Destilasi Kering dan Nilai Kalor 9 Jenis Kayu dari Nusa Tenggara Barat, Buletin Penelitian Hasil Hutan, 15(1), hal. 94-100.

Mousavioun, P. and Doherty, W.O.S., (2010), Chemical and Thermal Properties of Fractionated Bagasse Soda Lignin, Ind. Crops Prod., 31, pp. 52-58.

Nassar, M.M., (2003), Thermal Behavior of Bagasse Kraft Black Liquor, Energy Sources, 25, pp. 837-844.

Nugraha, J. and Fatimah, I., (2005), Identifikasi Hasil Pirolisis Serbuk Kayu Jati Menggunakan Component Analysis, Jurnal Ilmu Dasar, 6(1), hal. 41-47.

Pari, G., Sofyan, K., Syafii, W., dan Buchari, (2003), Suhu Karbonisasi dan Perubahan Struktur Arang Serbuk Gergaji Jati, Jurnal Teknologi Hasil Hutan, 16(2), hal. 70-79.

Pari, G., Sofyan, K., Syafii, W., dan Buchari, (2004), Pengaruh Lama Aktivasi Terhadap Struktur dan Mutu Arang Aktif Serbuk Gergaji Jati (Tectonagrandis L.F), Jurnal Teknologi Hasil Hutan, 17(1), hal. 33-44.

Rousset, P., Caldeira-Pires, A., Sablowski, A., and Rodrigues, T., (2011), LCA of eucalyptus wood charcoal briquettes, J. Clean. Prod., 19, pp. 16471653.

Shafizadeh, F., (1984), The Chemistry of Pyrolysis and Combustion, in Rowell, R(Ed.), The Chemistry of Solid Wood, Advances in Chemistry Series 207, American Chemical Society, Washington, D.C., pp. 489-530.

Sjostrom, E., (1993), Wood Chemistry: Fundamentals and Applications, $2^{\text {nd }}$ Ed., Academic Press, Inc, New York, pp. 144-161.

Tejado, A., Pena, C., Echevarria, J.M., and Mondragon, I., (2007), Physico-chemical characterization of lignin from different sources for use in phenol-formaldehyde resin synthesis, Bioresour. Technol., 98, pp. 1655-1663.

Worasuwannarak N., Potisri P., and Tanthapanichakoon W., (2004), Carbonization Characteristic of Thai Agricultural Residues, in The Proceeding of the Joint International Conference on Sustainable Energy and Environment (SEE), December 1-3, 2004, HuaHin, Thailand, pp. 302-305.

Yuan, T.Q., He, J., Xu, F., and Sun, R.C., (2009), Fractionation and physico-chemical analysis of degraded lignins from the black liquor of Eucalyptus pellita KP-AQ pulping, Polym.Degrad. Stabil., 94, $1142-1150$ 
Zapusek, A., Wirtgen, C., Weigandt, J., and Lenart, F., (2003), Charactersation of Carbonizate Produced From Velenje Lignite In Lab-Scale Reactor. ActaChim., 50, pp.789-798.
Zhao, X. and Liu, D., (2010), Chemical and Thermal Characteristics of Lignins Isolated From Siam Weed Stem by Acetic Acid and Formic Acid Delignification, Ind. Crops Prod., 32, pp. 284-291. 